\title{
Pola Perubahan Ziarah Makam sebagai Arena Sosial
}

\author{
Suherman Arifin \\ Universitas Indonesia
}

*Correspondence address: suhermanarifin2111@gmail.com

\section{踠 \\ ISSN: 1979-4703 (p) \\ ISSN: 2527-9726 (e)}

\section{Keywords:}

Grave Pilgrimages, Traditions, Social Arenas

\begin{abstract}
A B S T R A C T
The changing pattern of the grave pilgrimage as a social arena has undergone various changes. The tradition of pilgrimage to the tombs has been going on bundreds of years ago and in Islam. This study aims to determine how the pattern of changes in the grave expedition as a social arena. This article discusses habitus, arenas, social capital and practices that occur in society. Qualitative data with case studies are the approach used in the analysis. The data collection technique was carried out in three different ways, including in-depth interviews, discussions with the Nazirite tombs and document studies. Secondary sources were obtained through the old Banten museum, regional libraries, Nadziran documents, news on the pilgrimage site announcement boards, previous research reports, related papers, journal articles, visualization documents in the form of photographs others. The data analysis technique starts with data reduction, data presentation and concluding. This research resulted in several findings including grave pilgrimage as an arena for a family gathering, an arena for healing mental illnesses, an arena for work images, an arena for spiritual bealing, an arena for bereditary ritual habitus, and a ball for symbolic power.
\end{abstract}

\section{A B S T R A K}

Pola perubahan ziarah makam sebagai arena sosial mengalami berbagai perubahan. Tradisi ziarah makam sudah berlangsung ratusan tahun yang lalu dan dalam agama Islam. Tujuan studi ini adalah untuk mengetahui bagaimana pola perubahan ziarah makam sebagai arena sosial. Artikel ini membahas tentang habitus, arena, modal dan praktik sosial yang terjadi di masyarakat, data kualitatif dengan study kasus merupakan pendekatan yang digunakan dalam menganalisis. Teknik pengumpulan data dilakukan dengan tiga macam cara yaitu meliputi wawancara mendalam, diskusi dengan pihak keNadziran makam dan studi dokumen. Sumber sekunder diperoleh melalui musium Banten lama, perpustakaan daerah, dokumen ke-Nadziran, berita yang ada di papan pengumuman lokasi ziarah, laporan penelitian sebelumnya, makalah-makalah terkait, artikel jurnal, dokumen visualisasi berupa foto-foto, dan lain-lain. Teknik analisis data dimulai dari reduksi data, penyajian data serta penarikan kesimpulan. Penelitian ini menghasilkan beberapa temuan diantaranya: ziarah makam sebagai arena berkumpul keluarga, arena penyembuhan penyakit mental, arena pencitraan, arena pekerjaan, arena perbaikan spiritual, arena habitus ritual turun temurun, dan arena kekuasaan simbolik. 


\section{Pendahuluan}

Pola perubahan ziarah makam saat ini dibandingkan dengan 10 atau 20 tahun yang lalu telah bergeser, dari makna spiritual menjadi suatu arena sosial untuk berbagai tujuan dan kegiatan. Dengan tujuan tertentu ziarah makam mulai memudar, hal ini sengaja diciptakan oleh agen atau aktor untuk mempengaruhi nilai-nilai spiritual yang saat ini mulai berubah, pola perubahan tersebut memaknai ziarah makam sebagai suatu wisata religi yang menitikberatkan pada unsur wisatanya, bukan pada prosesi ziarahnya dan ini akan merubah image dari peziarah menjadi kurang bermakna. Sebelum terjadinya perubahan tersebut, ziarah makam merupakan suatu ritual sakral yang menjadi upacara keagamaan sebagai warisan turun temurun. Sejak ziarah makam diperbolehkan untuk berdoa dan mengenang jasa-jasa si penghuni makam atau tokoh yang diziarahi dapat dijadikan suri teladan bagi generasi penerus. Pola-pola perubahan tentang ziarah makam sebagai suatu arena sosial banyak disebabkan oleh beberapa faktor yang mempengaruhinya dan faktor-faktor tersebut sulit untuk dihindari baik oleh lingkungan maupun oleh individu-individu.

Perubahan sosial pada ziarah makam sebagai arena sosial terjadi akibat dari beberapa faktor (Soekanto, 2012), yang mempengaruhinya bisa faktor internal (berasal dari dalam masyarakat) dan juga faktor eksternal (berasal dari luar masyarakat). Faktorfaktor internal antara lain; adanya komunikasi atau interaksi yang terjalin diantara masyarakat, cara pola pikir dari masyarakat, terjadinya konflik, revolusi dan lain-lain. Sedangkan faktor Eksternal terdiri dari; bencana alam, peperangan, perubahan iklim dan pengaruh budaya lain. Dengan adanya modernisasi, budaya-budaya yang ada di Indonesia sudah mulai ditinggalkan karena dianggap sudah ketinggalan zaman. Contohnya adalah kebudayaan kejawen pada masyarakat jawa, meskipun masih ada masyarakat pedesaan yang melakukannya tapi sudah tidak banyak, karena hal tersebut dipandang sebagai mistis atau takhayul sehingga banyak masyarakat yang sudah tidak percaya.

Perubahan sosial yang terjadi pada masyarakat secara umum tidak jauh berbeda. Indonesia sendiri sebagai negara merdeka dapat menerima perubahan yang dibawa oleh faktor eksternal yang sangat mempengaruhi budaya asli, hal ini sangat dirasa oleh masyarakat yang salah satu cirinya adalah kurang menghargai budaya asli yang dengan mudah dan cepat dapat meniru budaya dari luar. Menjadi suatu keprihatinan tersendiri bahwa budaya sendiri dianggap kuno atau ketinggalan zaman oleh sebagian masyarakat di Indonesia. Di berbagai daerah di Indonesia, masyarakat Indonesia sangat menghormati orang yang datang dari luar, sopan santun ciri khas masyarakat Indonesia dalam menerima masyarakat dari luar. Sopan santun sendiri secara umum diartikan sebagai budi bahasa yang menjadi ciri khas masyarakat. Masyarakat sangat menjunjung tinggi budaya kesopanan dan adat istiadat yang berisi pedoman hidup bagi kebanyakan penduduk dan mempunyai nilai potensi jati diri yang dijaga secara bersama. Penghormatan terhadap budaya sendiri sudah menjadi suatu tradisi yang mengakar dan sangat dijaga keberadaannya. Hal tersebut menjadi suatu kewajiban yang harus terus dipelihara dan dilestarikan baik dalam hal beragama maupun lainnya yang tidak terlepas dari tradisi adat 
masyarakat yang masih tetap melakukan penghormatan terhadap leluhurnya. Salah satu contoh adalah masyarakat masih tetap menjalankan ritual ziarah makam sambil melantunkan ayat-ayat suci al-Qur'an. Hal ini merupakan suatu adat yang harus tetap dijaga disaat hari-hari besar keagamaan maupun hari-hari lainnya, sebagai ungkapan rasa terima kasih kepada tokoh yang telah berjasa dan dihormati..

Ziarah makam dan agama jelas tidak berdiri sendiri, agama sebagai struktur sosial mutlak telah ditentukan oleh Tuhan Yang Maha Esa sebagai tuntunan hidup bagi manusia yang berakal sedangkan Ziarah makam merupakan kultur sosial masyarakat sebagai bentuk penghormatan pada orang-orang yang telah berjasa. Ziarah makam diperbolehkan sekaligus menjadi bagian dari agama. Sedangkan doa-doa yang dipanjatkan kepada Tuhan Yang Maha Esa merupakan proses sosial yang dilakukan oleh masyarakat. Aturan agama dan turunannya merupakan suatu hal yang tidak bisa diganggu gugat. Agama membolehkan ziarah makam,. Ziarah makam adalah bagian dari anjuran agama untuk menghormati orang-orang yang telah lebih dahulu menghadap kepada Tuhan Yang Maha Esa. Ziarah makam bagian dari tradisi keagamaan, keduanya saling mengisi dan menjadi tuntunan dalam menjalani kehidupan di dunia ini. Ziarah makam sebagai suatu hubungan personal, bentuk interaksi sosial dalam suatu arena sosial dimana para aktor atau agen berkumpul untuk suatu niat tertentu yang diucapkan dalam hati, atau suatu penghormatan kepada orang yang telah tiada, mengenang jasa-jasanya dan sekaligus selalu mengingat akan datangnya kematian yang tentu saja tidak bisa dielakkan oleh setiap mahluk hidup, bahwa setiap mahluk hidup pasti akan mengalaminya.

Diawal datangnya agama Islam, ziarah makam sempat dilarang oleh Nabi Muhammad SAW (at-Tirmidzi dalam Hadist Hasan Shahih), karena mengingat iman umat Islam belum kuat dan setelah Nabi menilai umat Islam sudah kuat keimanannya, maka Nabi membolehkan untuk melakukan ziarah makam yang tentunya atas seizin Allah SWT dan dimulai oleh Nabi sendiri. Ziarah makam dalam tradisi Islam merupakan bagian dari ritual keagamaan serta telah menjadi budaya dalam masyarakat. Kebudayaan mengandung pengertian yaitu cara hidup atau seluruh aspek pemikiran dan perilaku manusia yang diturunkan dari generasi ke generasi selanjutnya melalui proses pembelajaran (Rahman, 2011). Ziarah makam merupakan arena sosial dalam struktur sosial yang sudah ada sejak dahulu dan menjadi kebiasaan (Habitus) yang sudah mengakar dari masa ke masa. Hal ini di wujudkan dalam adat atau tradisi yang sering kali menjadi mistis. Adat dan tradisi merupakan kegiatan yang berlangsung secara terus menerus tanpa bisa dihentikan oleh siapapun dan terus dilestarikan sepanjang masa atau selama manusia masih ada. Adat dan tradisi adalah sesuatu yang sulit ditolak. Terlepas dari pro dan kontra, adat dan tradisi jalan terus (Geertz, 1983). Pada awal kedatangan agama Islam, akidah umat Islam masih prematur, makam dijadikan tempat untuk meminta-minta dan dikultuskan menjadi tempat untuk mencari keberkahan, kekayaan dan kesuksesan dalam kehidupan dunia. Setelah akidah agama Islam sudah kuat, maka ziarah makam diperbolehkan hanya untuk berdoa bagi penghuni makam dan mengingat akan datangnya kematian yang akan dialami oleh setiap mahluk yang bernyawa (Miskawi, 2007).

Ziarah makam, salah satu tradisi keagamaan turun temurun menjadi habitus dari generasi ke generasi sudah banyak mengalami perubahan. Berbagai macam pola 
perubahan ziarah makam dijadikan sebagai arena sosial untuk berbagai kegiatan dan tujuan tertentu. Ziarah makam dijadikan sebagai jembatan untuk mencapai suatu keinginan, sehingga makna ziarah makam saat ini sudah melenceng jauh dan mulai kehilangan kesakralannya (Koentjaraninggrat, 1984). Ziarah makam merupakan kebutuhan spiritual, banyaknya persoalan dalam hidup ini mengakibatkan rasionalitas tidak berdaya, sehingga timbullah kecemasan, ketakutan, kegelisahan menghantui kehidupan. Berziarah, salah satu alternatif untuk mengatasi dan menenangkan jiwa yang sedang kacau. Dengan berdoa dan merenung di arena ziarah makam, kehidupan dunia yang serba materialistis akan teratasi dengan berdoa dan mengingat kematian. Di era modernisasi saat ini, orang berlomba-lomba mencari harta sebanyak-banyaknya tanpa mengingat datangnya kematian. Tradisi keagamaan berupa ziarah makam sedikit demi sedikit mulai diabaikan. Kalaupun masih mengingat, ziarah makam hanya dijadikan tempat pencitraan saja. Makna perubahan ziarah makam sebagai arena sosial juga dapat dijadikan sebagai tempat berkumpulnya modal sosial. Modal sosial yang dimiliki agen akan berpengaruh pada status sosial. Memiliki berbagai modal sosial, agen dapat mendominasi lingkungan sosial dan masyarakat sekitar akan terdominasi oleh agen tersebut. Pola perubahan ziarah makam dapat berbentuk bermacam-macam, mulai dari berdoa, sebagai pertemuan keluarga, pengobatan, pencitraan, transmisi spiritual, membuka peluang usaha, dan sebagainya. Gejala-gejala sosial tersebut sulit dihilangkan akibat pengaruh dari arus globalisasi. (Arifin, 2007).

Ziarah makam merupakan arena sosial berkumpulnya modal sosial, berbagai modal sosial dipertaruhkan di arena makam. Peziarah yang datang pasti membawa berbagai modal sosial, baik modal ekonomi (uang, simpanan, aset), modal pendidikan (gelar, penghargaan), modal simbol (prestise, status, otoritas), maupun modal budaya (koleksi, koneksi dan objek). Umumnya modal-modal tersebut menunjukkan keberadaan status sosialnya di masyarakat dan ini menjadi harapan dari para penyandang disabilitas di sekitar arena ziarah makam. Mereka berharap akan mendapat rezeki yang berlebih dari peziarah. Arena ziarah makam juga menjadi suatu pertarungan terutama pertarungan kekuasaan simbolik agen (Pejabat, Politisi, Pengusaha, dan karyawan), agen akan menampilkan gaya kehidupannya yang tentunya akan berbeda dengan masyarakat biasa. Mereka memperlihatkan berbagai modal sosial yang dimiliki dan mereka akan mempengaruhi masyarakat sekitar dengan suatu penampilan yang berbeda dari umumnya. Dengan perubahan makna ziarah makam, apakah masih dapat dikatakan bahwa ziarah makam merupakan tradisi keagamaan ?. Bergesernya makna ziarah makam sebagai arena sosial merupakan suatu perubahan sosial yang terjadi dari pengaruh kekuatan sosial baik datang dari agen ataupun aktor dengan modal sosial yang dimiliki maupun kekuasaan simbolik para agen atau aktor yang berpengaruh. Praktik ziarah makam menjadi ajang untuk mempertaruhkan berbagai modal sosial yang akan berimplikasi pada agen atau aktor yang mendominasi dan yang terdominasi. Makna ziarah makam sedikit demi sedikit akan berubah menjadi suatu pertarungan kekuasaan simbolik yang diperlihatkan oleh agen atau aktor. 


\section{Tinjauan Pustaka}

\section{Teori Arena/Medan (Field) Pierre Felix Bourdieu}

Berdasarkan teori yang dikemukakan oleh Pierre-Felix Bourdieu. Dalam analisisnya, Bourdieu sangat memahami tentang realitas sosial sebagai hubungan antara individu (agen/struktur Subjektif) dan struktur objektif. Hubungan ini meliputi unsur subjektif dengan mental seseorang, struktur yang dialami oleh seseorang dan struktur kognitif yang berinteraksi dengan struktur objektif. Praktik merupakan hasil dari hubungan dialektik yang menjelaskan struktur subjektif dan objektif yang memunculkan "Habitus" dan "Arena" (ranah/ field). Habitus mengarah pada apa yang dimiliki agen. Perjumpaan habitus dalam suatu arena akan menghasilkan "Modal" yaitu kapital, sosial, ekonomi, kultural dan simbolik. Kekuasaan simbolik terdiri dari Habitus, arena dan kapital. Habitus ada didalam pola pikir aktor, arena ada diluar pikiran aktor sedangkan praktik-praktik akan terjadi antara individu atau kelompok sosial. Praktik merupakan hasil dari interaksi habitus dan arena atau ranah.

Habitus merupakan struktur kognitif (struktur subjektif) dari pengalaman sosial individu dengan individu lain dalam struktur objektif yang berada dalam ruang sosial. Habitus dan arena merupakan suatu perpaduan untuk mendapatkan posisi-posisi, habitus dan arena berada seimbang antara stabilitas dan perubahan. Bourdieu mengatakan bahwa habitus erat hubungannya dengan modal, habitus mempunyai peran untuk menunjukkan berbagai modal, diantaranya modal simbolik, modal ekonomi, modal sosial, modal budaya dan lain-lain. Modal sebagai dasar untuk mendominasi secara legitimite. Modal simbolik memunculkan kekuasaan simbolik dalam dunia sosial. Habitus adalah sebagai pedoman tindakan, dan arena sebagai tempat beroperasinya modal. Teori yang dikemukakan oleh Bourdieu bukan dari buah pikirannya sendiri, melainkan mengadopsi dari pemikir-pemikir sebelumnya yang menitik beratkan pada peran aktor atau subjektifvitas atau yang lebih dikenal dengan sebutan "strukturalisme-konstruktif. Kajiannya berupa "Sosiologi Kultural dan Sosiologi Reflektif” atau bisa disebut juga dengan istilah "Metasosiolog?".

Fokus utama sosiologi kultural adalah menganalisa tentang teori mengenai praktek manusia, yang merupakan paduan antara agen atau aktor dengan penjelasan objektivitas dalam suatu dimensi struktur yang membentuk kehidupan sosial manusia. Munculnya teori Bourdieu ini didasari oleh suatu pengalaman hidupnya sewaktu di Aljiers atau Aljazair dan keluarganya juga mempunyai andil besar dalam membentuk gagasan Bourdieu tentang habitus. Karya-karya ilmiahnya dipengaruhi oleh suatu perubahan habitus dan arena. Orientasinya mengarah pada hubungan dialektik antara struktur objektif dengan fenomena subjektif yang dipakai untuk mengamati suatu realitas sosial. Bourdieu sendiri menyebutnya dengan sebutan "Strukturalisme-Konstruktif" atau dengan istilah lain disebut juga "Strukturalisme Genetis" yang diartikan sebagai paduan antara analisis struktur objektif dengan riwayat mental seseorang.

Struktur objektif adalah kesadaran bebas, kehendak agen yang membimbing dan mengarahkan pada praktik agen atau representasi agen. Aktor dapat atau mampu berimprovisasi secara teratur walaupun hasil akhirnya tidak dengan kesengajaan atau 


\section{At-Taqaddum}

Vol. 12 No. 2 (2020) 135-154

disengaja. Salah satu kelemahan teori bourdieu adalah tidak mampunya mengatasi subjektivitas. Tapi inti karyanya adalah tentang pemikiran habitus dengan lingkungan serta hubungan interaksi keduanya. Ziarah makam merupakan suatu arena/medan (field) yang selalu ramai dikunjungi agen atau aktor yang tentunya memiliki berbagai modal sosial untuk datang ke Arena ziarah makam. Agen atau aktor mempunyai suatu tujuan yang berbeda-beda dalam memandang ziarah makam, karena setiap agen atau aktor mempunyai modal sosial yang berbeda-beda juga. Disinilah, Pola perubahan ziarah makam sebagai arena sosial sangat jelas, karena dilandasi oleh tujuan yang berbeda dan modal sosial yang berbeda.

Teori Bourdieu merupakan perpaduan antara struktur yang berfokus dalam menganalisa sistem dan ini dapat dikatakan sebagai teori yang campur aduk, karena banyak hal yang dijadikan perhatian dan terkait satu sama lain seperti membahas masalah habitus, Ranah/Arena, Modal sosial, Kekuasaan Simbolik, praktik dan lain-lain. Memang disatu sisi masalah tersebut saling terkait, tapi disisi lain teori ini menjadi teori yang sulit dicermati karena tidak terfokus pada penjelasan satu persatu, semua saling bersinggungan. Arena/Ranah yang dijabarkan oleh Bourdieu adalah suatu pengalaman hidup yang dialami sewaktu Bourdieu berada di asrama dan di aljazair. Out Of a Theory Practice menjelaskan tentang teori praktik sebagai upaya menggambarkan hubungan individu dengan individu lainnya dalam budaya mereka. Dalam bukunya Pierre Felix Bourdieu menjelaskan beberapa konsep penting dalam teori praktik. Batasan objektif dan objektifisme, struktur dan habitus, logika generative dan skema praktikal, struktur/Habitus dan power sebagai dasar dari teori kekuasaan simbolik.

Bourdieu berada diantara pendapat Levi Straus (strukturalisme) dan eksistensialisme Jean Paul Satre. Pendapat Levi straus menyatakan bahwa struktur merupakan sistem, sementara Jean Paul Satre melihat bahwa seseoranglah yang menentukan nasibnya sendiri . Kedua pendapat ini hampir sama seperti aliran "Qodariah dan Jabriyah dalam agama Islam". Bourdieu tidak sependapat dengan pernyataan bahwa struktur dan aturan bisa sepenuhnya mengekang kehendak individual. Disisi lain praktikpraktik sosial yang dilakukan oleh individu dapat menumbuhkan skema dasar dalam kehidupan manusia. Bourdieu mencontohkan bagaimana skema-skema di masyarakat Kabylia memunculkan hukum adat.

Habitus menjadi sumber dari pergerakan individu karena sifatnya yang individual. Habitus merupakan kumpulan dari modal ekonomi, sosial dan simbolik. Modal ekonomi menjadi modal yang paling mudah dikonversikan menjadi modal lain. Capital dimaknai sebagai kepemilikan seseorang terhadap sesuatu yang memungkinkan dirinya memenangkan pertarungan dalam sebuah arena. Capital dan Habitus yang tepat hanya akan tepat dalam Arena yang tepat pula. Ketiganya berkaitan satu sama lain.

\section{Metode Penelitian}

Studi ini menggunakan penedekatan kualitatif desktiptif. Pendekatan kualitatif deskriptif merupakan metode yang tepat untuk mendapatkan hasil dari observasi 
lapangan (field research). Mengambil data dari tempat yang akan dijadikan penelitian terutama dalam mengamati fenomena objek formalnya. Objek berupa gejala sosial atau perubahan sosial yang terjadi pada arena sosial ziarah makam. Prosesi ritual ziarah makam yang telah ditetapkan oleh pihak kenaziran makam. Dalam memanjatkan doa bagi penghuni makam, peziarah dipimpin oleh seorang ustad yang bertindak sebagai pemimpin doa yang diamini oleh peziarah. Setelah ustad selesai memimpin doa selanjutnya peziarah bisa meneruskan doanya berdasarkan niat masing-masing. Menganalisis gejala-gejala sosial, pola-pola perubahan sosial baik dari para peziarah maupun masyarakat sekitar makam untuk memperoleh gambaran mengenai pola-pola yang ditemukan, kemudian dianalisis kembali menggunakan teori objektif yang berasal dari tradisi-tradisi etnografik dan studi lapangan dalam antropologi dan sosiologi.

\section{Hasil dan Pembahasan}

\section{Pola Perubahan Ziarah Makam}

Lunturnya budaya lokal dan lambat laun mulai terlupakan, banyak diakui oleh Sebagian tokoh-tokoh agama, sebaliknya tokoh-tokoh agama harus menjadi pioner untuk lebih memperkenalkan budaya tradisi keagamaan dan peran tersebut harus lebih ditingkatkan untuk dapat dipublikasikan ke generasi selanjutnya. Informasi budaya setempat harus di lestarikan agar generasi selanjutnya bisa lebih mencintai kebudayaan sendiri sekaligus dapat mempelajari sejarah dan budaya bangsa sendiri terutama budaya asli daerah. Berbicara tentang budaya, tentu cakupannya sangat luas tidak hanya menyangkut kehidupan untuk dunia saja tapi bagaimana mempersiapkan segala sesuatunya untuk bekal hari kemudian menghadapi kematian. Karena setiap yang bernyawa pasti akan mengalami suatu peristiwa kematian. Di sinilah kembali digugah kepada khususnya tokoh-tokoh agama untuk menyampaikan pencerahan kepada generasi muda agar sejak dini bisa mempersiapkannya.

Ziarah makam merupakan suatu aktifitas sosial yang telah diketahui oleh umat manusia di berbagai belahan bumi ini, ziarah makam meliputi struktur sosial, proses sosial dan mampu melakukan suatu perubahan sosial baik kepada individu dengan individu, kelompok dengan individu, maupun kelompok dengan kelompok. Ziarah dan sosiologi secara hakiki sebenarnya ingin mengetahui keadaan tentang hubungan sosial dalam kehidupan bermasyarakat. Dalam melakukan aktifitas ziarah, individu ataupun kelompok sudah pasti berinteraksi, baik itu berinteraksi secara batin maupun berinteraksi secara fisik sesama peziarah. Dalam kajian sosiologi terhadap ziarah makam, dapat dilihat dari Aspek -aspek apa saja ziarah dapat dikaji dengan menggunakan kacamata sosiologi. Hal ini sangat sulit bagi penulis untuk menjawabnya. Penulis akan mencoba menjawab dengan persepsi penulis sendiri. Pertama, Dalam melakukan aktifitas ziarah, individu ataupun kelompok sudah pasti akan berhadapan langsung dengan masyarakat. Kedua, ziarah makam berkaitan dengan hubungan sosial yang meliputi perilaku, tindakan, struktur, sistem sosial dan norma. Hal ini berlaku pada aktifitas ziarah di makam-makam keramat atau yang dikeramatkan seperti makam Wali, Sultan atau tokoh- 


\section{At-Taqaddum}

Vol. 12 No. 2 (2020) 135-154

tokoh Agama yang karismatik. Untuk ziarah kemakam keluarga atau makam umumnya hal ini tidak berlaku (Miskawi, 2007)

Dari sinilah, keterkaitan sosiologi dengan ziarah makam sangat erat karena menyangkut suatu hubungan sosial yang sulit untuk dipisahkan. Sebelum sosiologi dipelajari dan dikembangkan, tradisi ziarah makam lebih dulu datang ke dunia ini. Masyarakat primitif pun mengenal ritual ziarah, yang di masa itu masih sangat tradisional dan mengikuti aturan yang ditentukan oleh kepala suku atau orang yang dipandang sakti. Tapi semakin peradaban menjadi modern, tradisi ziarah mengalami suatu perubahan, yang dulunya kurang diperhatikan tapi sekarang menjadi suatu kajian ilmu pengetahuan. Bahkan sudah menjadi suatu destinasi pariwisata yang tentunya akan menjadi daya tarik tersendiri dan menjadi suatu peluang peningkatan ekonomi masyarakat.

\section{Arena Berkumpul Keluarga.}

Berbagai macam dilakukan, ada keluarga yang tradisi ziarah makam dan makan Bajambau Agbi Yayo Onam yang dilakukan oleh masyarakat di Dusun Uwai, Desa Muara Uwai, Kecamatan Bangkinang Seberang, Kampar, Riau sambil membaca doa. Tradisi ini memiliki ciri khas yang unik yaitu selurub sanak saudara dari perantauan akan pulang kampung untuk berkumpil bersama pada tanggal 7 Syawal untuk. melakukan ziarah makam yang dilanjutkan dengan makan bersama di masjid-masjid dan rumah penduduk. Tradisi ini diturunkan sebagai ibadah yang sekaligus menjadi ajang silaturrahmi. Semua perantau yang ada di luar negeri sekalipun pulang semua untuk melaksakan tradisi ziarah makam. hal ini dilakukan dengan alasan untuk mempererat tali silaturabim antar keluarga. Biasanya kejadian-kejadian seperti ini dilakukan oleh umat Islam yang mendapatkan warisan dari nenek moyangnya yang tentunya selalu dipraktekkan dari generasi ke generasi.

Kejadian semacam itu lazim disebut "Tradisi" sebagai rekonsiliasi keluarga, terutama keluarga jauh yang datang hanya saat-saat dihari raya dan pola tersebut selalu terjadi semacam reuni antar keluarga dan itu dapat diterima sebagai "Budaya" yang menjadi sesuatu yang dirasa tak perlu dipertanyakan lagi. Merujuk pada pendapat Clifford Geertz yang menyatakan bahwa budaya adalah sistem pemaknaan, maka lumrah ada tafsir seperti diatas dan ini untuk memahami apa yang dinyatakan dengan suatu kejadian berulang atau gejala sosial-budaya (https://riaupos.jawapos.com). Ziarah makam, sejatinya bukan peristiwa duka-cita, melainkan suka-cita. Ada makna perdamaian di situ, antara anggota keluarga atau kerabat yang bertemu di satu titik. Saling mengubur perselisihan, di atas dasar pengalaman kebaikan bersama mendiang di masa lalu. Beda dengan ritus kolektif alam fana yang membumi, ritus kolektif alam baka bersifat transeden. Orientasi ritus kolektif alam baka adalah harapan kebaikan atau kedamaian kelak di akhirat, yang dibayangkan adalah sesuatu yang transeden, sebuah "surga" menurut pemaknaan teologis. Doa keluarga di Makam lazimnya bertujuan ganda. Pertama, mohon agar arwah mendiang diterima dalam istirahat damai disurganya. Kedua, mohon agar anggota keluarga yang ditinggal dikuatkan melangkah di jalannya, agar kelak arwahnya boleh bersatu dengan mendiang disurganya. Jadi yang dibayangkan saat berziarah makam, selain kebaikan dimasa lalu, juga persatuan keluarga dalam damai, ini berarti 
peziarah berdamai dengan kematian yang pasti menghampirinya kelak. Ziarah makam dengan demikian sebenarnya melipat masa lalu dan menyongsong masa depan yang lebih baik, damai pada satu titik waktu kini. Dengan begitu, ziarah makam sebagai ritus kolektif yang bermakna rekonsiliasi dengan masa lalu dan masa datang. Intinya kematian adalah simpul kebaikan, yang mempertalikan manusia dalam kedamaian dan kebaikan, baik itu suatu kenangan akan masa lalu maupun dalam impian akan masa yang akan datang. Semua itu teralami dalam satu titik ruang dan waktu, disini dan kini, di suatu tempat yang dinamakan ziarah makam.

\section{Arena Penyembuhan Penyakit Mental}

Menurut Hakim (2017), kecemasan dan kegelisahan membuat seseorang menjadi kurang nyaman dalam menjalani kehidupan ini, sehingga orang akan mencari alternatif pengobatan jiwa. Salah satu alternatif pengobatan jiwa adalah dengan melakukan ziarah ke makam yang dianggap dapat menenangkan jiwa yang sedang gelisah dan mengobati kecemasan hidup akibat dari tekanan yang melebihi kemampuan. Melakukan ziarah makam merupakan salah satu obat untuk mengatasi kegersangan hati dan tentunya akan mendapatkan ketenangan jiwa, karena ziarah makam menjadikan seseorang akan lebih dekat dengan Allah SW'T. Mereka dapat melakukan ziarah makam bisa secara rutin atau seminggu sekali daripada mereka harus ke dokter jiwa yang tentunya akan mengeluarkan biaya yang tidak sedikit. Dengan melakukan ziarah, orang akan selalu ingat akan kematian dan akan berfikir kemana ujung dari kehidupan ini, dan bagaimana harta yang dicari dengan susah payah akan dimanfaatkan.

Di era globalisasi sekarang ini persaingan disegala bidang semakin ketat, bagi mereka yang tidak berpengetahuan dan tidak mempunyai keterampilan akan semakin tersingkir dan terjepit yang pada akhirnya atau puncaknya akan mengalami kegundahan bahkan sampai guncangan jiwa akibat dari semua itu. Orang akan menjadi cemas dan kecemasan ini sebagai dampak dari sulitnya mendapatkan peluang pekerjaan. Batin yang merasa tidak tenang akan menjadikan seseorang merasa bersalah dan akan berfikir untuk mencari jalan keluar dari kesulitan hidup yang menimpanya. Obat yang paling mujarab adalah dengan berziarah ke makam yang dianggap mempunyai kharomah. Disini seseorang dapat merenungkan perbuatannya baik masa kini maupun masa lalunya dan memohon kepada Allah SWT untuk membukakan pintu maaf serta dilapangkan jalan untuk mengatasi kesulitan hidup.

Dengan berziarah, orang akan mengenang perbuatannya yang telah dilakukannya, baik perbuatan baik maupun perbuatan buruk. Orang akan introspeksi diri, sudah sejauh mana kita mandalami perintah agama dan kenapa selama ini kita menganggap agama menjadi nomor dua setelah pekerjaan. Inilah bahan yang harus kita perbaiki untuk mengobati perasaan cemas, gelisah, kurang tenang dan stres dalam menghadapi hidup ini. Kecemasan dan ketegangan di dalam kehidupan ini akan mendorong seseorang mencari jalan penyelesaiannya. Ziarah ke makam dengan mendekatkan diri kepada yang Kuasa adalah pilihan terbaik, yang tidak berbayar. Ini pengobatan alternatif yang sangat ampuh untuk mengatasi problem kejiwaan, menjadikan hidup lebih tenang dan damai serta 


\section{At-Taqaddum}

Vol. 12 No. 2 (2020) 135-154

dapat mengatasi masalah yang sulit sekalipun.

Dengan secara rutin, orang melakukan ziarah, maka segala yang menjadi kebutuhan hidup di dunia sedikit demi sedikit akan dikurangi dan beralih kepada urusan agama, lebih rajin menjalankan perintahnya sebagai persiapan hidup dikemudian hari dan akan berimbas pada lingkungan dimana seseorang tersebut tinggal dan suatu saat jika telah datang panggilan, kita sudah mempersiapkan diri untuk menghadapinya, bekal yang kita bawa akan mumpuni dan kita dapat mempertanggungjawabkan segala perbuatan kita selama kita hidup di dunia ini. Segala keraguan yang selama ini menghinggapi hidup kita secara otomatis akan hilang, kecemasan jiwa yang menjadi momok dalam hidup ini berubah menjadi ketenangan jiwa. Agama yang selama ini kita tinggalkan akan menjadi konsumsi jiwa untuk mengobati batin yang gelisah, dan semua yang kita kerjakan akan semakin ringan untuk diselesaikan. Apa-apa yang kita lakukan akan mudah teratasi serta ibadah yang selama ini kita tinggalkan akan menjadi rugi jika kita tidak menjalankannya.

Demikianlah penjelasan singkat, mengapa ziarah makam dapat menjadikan obat alternatif untuk mengobati kegelisahan, kecemasan dan kegundahan hati. Karena dengan melakukan secara rutin berziarah, kita akan selalu mengingat kehidupan di akhirat, kehidupan di dunia ini hanya bersifat sementara, ada batasannya dan batasan tersebut sangat singkat, tidak terasa bahwa kita sudah dipenghujung hidup karena kita sudah tua. Dengan persiapan yang sudah kita kumpulkan, akan membuat kita lebih siap untuk menghadap yang kuasa dan apa-apa yang telah kita raih selama ini, selama kita hidup di dunia akan kita tinggalkan, dan harta yang selama ini kita kumpulkan dan kita kejar sama sekali tidak dapat menolong kita, karena yang menolong kita adalah amal perbuatan baik kita selama hidup di dunia sesuai dengan ajaran agama yang menjadi tuntunan hidup (Arifin, 2007).

\section{Arena Pencitraan.}

Sudah menjadi hal yang lumrah, mungkin sejak berdirinya NKRI ini, setiap siapapun yang akan terjun dalam ajang kontestasi politik dimanapun di tanah air ini, tradisi ziarah makam menjambangi para mendiang ulama kharismatik, pahlawan nasional, atau tokoh-tokoh masyarakat menjadi pemandangan umum. Seakan sulit dibedakan, mana tradisi keagamaan dan mana bentuk pencitraan politik, karena keduanya lebur dan masing-masing "Muatan" ada dalam fenomena keduanya. Jika saya mengatakan, ziarah makam menjelang kontestasi hanyalah pencitraan, tentu saja akan mendapatkan penolakkan dari pihak-pihak yang berkeyakinan, ziarah makam adalah menjalankan tradisi keagamaan, bukan bentuk pencitraan politik semata. Walaupun disisi lain, jika memang ziarah makam menjadi tradisi keagamaan, kenapa sering kali dilakukan saat-saat menjelang kontestasi ? Sejatinya, manusia adalah mahluk peziarah, karena hampir disetiap inci kehidupannya selalu bergerak. Kata "Ziarah" atau "Zaara" yang memiliki konotasi "seseorang yang berpindah/berkunjung karena suatu tujuan, ingin bertemu dengan seseorang atau maksud tertentu".

Hampir dipastikan, manusia bukanlah mahluk yang berdiam diri namun selalu bergerak, "Berziarah" bertemu dengan banyak orang, bersosialisasi, bahkan dalam durasi 
waktu yang tak terbatas. Dalam konteks tradisi atau budaya seperti dalam agama Islam, ziarah tidak selalu ditujukan bagi seseorang yang masih hidup, namun kepada mereka yang pernah memiliki jasa-jasa kemanusiaan, walaupun sudah meninggal. Entah kenapa, tradisi ziarah makam yang sering dilakukan para kontestasi politik jelang digelarnya pemilihan umum, seperti sekedar ingin mendapatkan "Pengakuan" dari masyarakat, bahwa mereka adalah bagian dari pemelihara dan penjaga tradisi ziarah tersebut. Seringkali para kontestan takut mendapatkan sangsi sosial dari perlakuan hukum moral yang ada dalam sebuah masyarakat. Kita tentu seringkali menyaksikan, dari seseorang yang menjadi kontestan politik lokal, seperti bupati, walikota, atau gubernur, terlebih dalam sebuah ajang kontestasi politik nasional, seperti presiden, tradisi ziarah makam seperti hendak memperkuat "Citra Politik" sehingga mereka mampu terhindar dari beragam sangsi sosial yang berdampak pada elektabilitas mereka. Ziarah makam, tentu saja merupakan salah satu dari ajaran Islam dalam rangka menjalin silaturrahim antara "Yang Hidup" dan "yang mati". Berkunjung pada yang hidup, tentu saja jelas tujuannya, bertemu langsung dan mengetahui secara pasti tempat, niat dan tujuannya. Namun berkunjung kepada "yang sudah mati" selalu di identikkan dengan mendatangi pusaranya, walaupun sesungguhnya jiwa yang sudah terpisah dari raga, tentu saja bisa berada dimana saja, bahkan dapat "dikunjungi" atau "dihadirkan" setiap saat kita menginginkannya.

Seorang muslim yang berharap ingin bertemu dengan Rasullullah SAW, maka tidak harus datang ke pusaranya di Masjid Nabawi, Madinah, tetapi cukup melakukan "tirakat" seperti berdoa secara khusus dan menjalankan sholat sunnah, maka jika Allah SWT mengizinkan, Rasullullah SAW dapat hadir dalam setiap mimpi kita. Menariknya, soal ziarah makam saja, masih saja ada segelintir kelompok muslim yang mempersalahkannya, karena ziarah makam dengan memohon sesuatu kepada yang sudah "mati" jelas dianggap sebagai perbuatan syirik yang dosanya sulit terampuni. Sulit juga rasanya kita membedakan, mana sebuah ziarah makam yang bermakna silaturrahim dengan mendoakan dan memohonkan ampunan bagi mereka yang telah terlebih dahulu meninggalkan kita, dengan dorongan dan muatan niat kita untuk mendapatkan "barokah" dan mungkin saja meminta "restu" agar segala yang kita rencanakan diberikan kelancaran dan kesuksesan. Bukankah berdoa untuk segala kemudahan dan kesuksesan hidup itu mestinya langsung saja kepada Tuhan. Akan semakin kabur lagi makna ziarah makam jika dilakukan menjelang kontestasi politik. Silaturrahim kepada "Yang Mati" dengan mendoakan dan memohonkan ampunan, mencari restu dan keberkahan, ataukah pencitraan karena khawatir akan sangsi sosial.

Di Indonesia, tradisi ziarah makam beserta fenomena "Ngalap Berkah" telah menjadi warisan tradisi turun temurun yang mengakar dalam tradisi "Nahdlatul Ulama" (NU). Ormas Islam terbesar ini disebut sebagai penganut tradisionalisme, karena memang penjagaannya atas nilai-nilai kultur masyarakat dan budaya Islam Nusantara hingga saat ini. Membedah fenomena ziarah makam dalam tradisi NU ini juga sulit dibedakan, mana yang benar-benar memiliki tujuan "lurus" dalam berziarah, atau sekedar "Ta'zim" (penghormatan) atas jasa para ulama/sultan yang senantiasa berjuang demi umat, mendoakannya dan memohonkan ampunan untuknya, atau ada juga yang 
terkadang melampaui batas, "Meminta" dan bahkan "Meyakininya" bahwa merekalah yang dapat mengabulkan seluruh keinginannya, termasuk keinginannya memenangi sebuah kontestasi politik. Bagi saya, tanpa ziarah makam sekalipun, manusia memang mahluk peziarah, tak pernah berhenti untuk bergerak dan berpindah. Bahkan, ketika tidurpun, manusia tetap bergerak, dimana jantung dan aliran darah tetap berfungsi dan bergerakl sesuai jalurnya. Bahkan tanpa sadar, sesungguhnya bumi yang selama ini kita pijak, selalu bergerak tak pernah diam. Ziarah makam, barangkali adalah "motivasi" yang dapat menggerakkan, tidak hanya "yang hidup" tetapi juga "yang mati", karena doa-doa yang disampaikan oleh yang masih hidup, berdampak kepada mereka yang sudah tiada. Doalah yang dapat "menghidupkan " yang mati, bukan ziarah itu sendiri, karena doa jelas melahirkan nuansa emosi yang pada akhirnya saling terhubung dan menjalin silaturrahim.

Itulah kenapa, suasana ziarah makam yang dilakukan para kontestan politik yang kemudian di "ekspose" banyak media, tak lebih dari sekedar bentuk "Pencitraan" berharap tak jatuh kepada mereka sangsi sosial kerena melanggar hukum moral dari masyarakat. Jangan sampai, seakan-akan secara sadar, para kontestan malah mengeksploitasi yang sudah mati, seakan-akan dengan berziarah ke pusaranya mereka mendapat "Restu" dan "Dukungan" dari mereka. Pertanyaannya, jika memang para kontestan politik ini tidak melakukan ziarah makam kepada orang-orang tertentu, akankah gugur pencalonannya? atau gagalkah nanti dalam ajang kontestasi politik?. Disinilah uniknya politik, tidak ramai di dunia nyata, dunia maya, bahkan mungkin di dunia alam gaib (www.alinea.id).

\section{Arena Pekerjaan.}

Ziarah makam di ibaratkan sebagai sebuah pasar, yaitu pasar rohani, dimana yang datang akan memburu karomah yang diyakini dapat merubah kehidupannya. Bagi masyarakat sekitar, dengan kedatangan para peziarah merupakan berkah tersendiri, berkah yang tentunya akan berimbas pada ekonomi keluarga. Ziarah makam merubah status sosial yang awalnya seseorang pengangguran menjadi mempunyai pekerjaan . Hal ini juga akan berdampak pada tingkat kriminalitas yang menurun, karena adanya penghasilan. Orang akan merasa tenang tanpa mengganggu orang lain dan sekaligus menurunkan tingkat pengangguran. Pengaruh dari ziarah makam sangat luas yang tentunya akan dirasakan langsung pada masyarakat sekitar. Dari uraian diatas, dapat merumuskan pengaruh ziarah makam pada: 1). Mengurangi tingkat pengangguran. 2).Membuka peluang berusaha. 3). Menurunkan tingkat kriminalitas. 4). Melestarikan Budaya lokal. 5). Menjadikan kawasan destinasi. Efek dari ziarah makam dirasakan langsung, baik bagi masyarakat sekitar maupun bagi Pemerintah Daerah.

Dengan terbukanya peluang usaha tentu akan merubah kehidupan masyarakat sekitar dan kesempatan untuk menjadi sejahtera tidak tertutup. Perubahan hidup akan dialami dengan ramainya peziarah yang datang dengan membawa modal kapital yang akan didistribusikan kepada masyarakat, baik untuk sedekah, berbelanja atau memberikan infak ke masjid yang ada dilingkungan makam. Inilah hikmah dan karunia yang tak ternilai dari orang telah meninggal dunia yang masih menjadi daya tarik tersendiri bagi yang datang untuk menziarahinya. Bagi masyarakat sekitar, makam dijadikan berbagai 
macam peluang untuk mengais rezeki dengan berdagang, sebagai fotografer, pembaca doa, penyedia jasa permainan anak-anak, wc umum, dan lain lain. Hal ini akan mendongkrak perekonomian masyarakat sekitar untuk lebih baik dan dapat memenuhi kebutuhan hidup keluarganya. Bagi peziarah yang datang akan mendapatkan suatu kepuasan tersendiri, pengalaman dan ketenangan jiwa selama melakukan prosesi ziarah, mereka tidak memperdulikan berapa modal capital yang telah mereka keluarkan, mereka hanya berfikir bahwa niat dan maksudnya telah terpenuhi dan perjalanan yang jauh tidak dirasa karena mereka merasa puas telah melaksanakan ziarah makam ke salah satu tokoh.

Hikmah dari ziarah makam berdampak pada semua segi kehidupan, baik dunia maupun akhirat, karena dengan berziarah orang akan menjadi lebih baik dan perbuatan yang selama ini kurang baik akan ditinggalkan, , ziarah makam akan membuat seseorang lebih dermawan dibandingkan sebelumnya, karena di momen ziarah orang diajarkan secara tidak langsung untuk ikhlas memberikan sedekah dan infak kepada kaum papa yang ada disekitar makam dan ini menjadi habitus secara terus menerus dan tidak hanya dilakukan pada saat ziarah saja, tetapi dilakukan juga ditempat lain. Demikianlah penjelasan singkat tentang pengaruh ziarah makam terhadap kesempatan berusaha, untuk meningkatkan kesejahteraan hidup bagi masyarakat sekitar dan keluarga, manfaat dan barokah yang diberikan oleh Allah SWT melalui ziarah makam tidak putus-putus dan sudah seharusnya manusia bersyukur atas nikmat yang telah diberikan.

\section{Arena Perbaikan Spiritual}

Silaturahim dan berziarah memberikan pandangan dan pengalaman yang luas ditengah aktifitas keberagaman dan praktek sosial yang sedang berlangsung. Berziarah ataupun berkunjung tidak terbatas kepada sanak family maupun kerabat dekat saja, hal ini juga bisa dilakukan untuk mengunjungi tempat-tempat yang memiliki nilai-nilai kesejarahan, baik sejarah nubuat maupun jejak peradaban manusia. Berkunjung kepada sejarah nubuat seperti halnya telah dipraktekkan dan dianjurkan oleh Islam Seperti ziarah ke Ka'bah, Masjidil haram, Gunung Uhud, Bukit Shafa dan Marwa, Jabal Rahman dan tempat-tempat bersejarah lainnya. Sedangkan berkunjung kepada tempat yang menjadi sejarah peradaban manusia antara lain adalah; Taj Mahal, Perpustakaan di Mesir, Perpustakaan di Roma dan Leiden, Belanda.

Ziarah makam merupakan praktek keberagamaan yang baik karena selain memberikan kebaikan kepada si mayit, ziarah makam juga memiliki kebaikan bagi peziarah itu sendiri. Ziarah makam dimaksudkan untuk bertawasul kepada sosok model yang telah mencapai insan kamil yang memiliki martabat nubuat, adalah sebagai media pengembangan keseimbangan psikis manusia yang mana dalam prakteknya ziarah makam melibatkan beberapa unsur seperti ; roh, hati, aql, dan nafs. Secara psikis saat manusia melakukan tawasul, energi rohnya telah menggerakkan dan mengalahkan pada energy yang lurus menuju Allah SWT, dan energy hatinya dapat mengokohkan rahasia kehidupan dan prinsip kematian, sedangkan energy nafs dapat beralih dari nafs al amarah menuju nafs al muthmainnah, sehingga akan lahir dan berakhir pada perjalanan yang baik (good ending). Dari pemahaman seputar ziarah makam inilah, kita bisa memahami bahwa 
praktek ziarah makam yang selama ini dilakukan umat Islam pada prinsipnya merupakan pengembangan spiritualitas manusia untuk lebih taqarrab (mendekat) kepada Allah SWT.

Pencerahan yang diperoleh lewat bertawasul kepada mereka yang telah memperoleh derajat insan kamil, atau yang telah mewarisi unsur-unsur nubuat dalam dirinya inilah yang menjadi barakah dari praktek ziarah makam. Dari sinilah masyarakat Islam jawa memahami adanya konsep Ngalap Berkah Waliyullah. Ngalap berkah disini sebagai ; Pertama, perolehan ilmu dan hikmah kesadaran Ilahiah dan Insaniah yang mengalir dari mayit yang telah menyandang gelar Waliyullah. Kedua, memperoleh cahaya nubuat dari insan yang telah memperoleh dan mencapai derajat Insan kamil. Ketiga, memperoleh integrasi sikap yang memadukan antara sikap peziarah dan waliyullah yang bersumber atas tajalli sifat-sifat Allah SWT yang mulia. Keempat, menjadikan semangat bermunajat dan memohon kepada Allah SWT dengan bantuan waliyullah tersebut. Kelima, perolehan nilai kebaikan yang bersumber dari semangat mengikuti jejak nubuat dan risalah kewalian. Mengenai doa dan tawasul (https://m.republikas.co.id).

\section{Arena Habitus Ritual Turun Temurun}

Ziarah makam yang sudah menjadi habitus tidak akan lapuk di makan zaman, walaupun saat ini zaman sudah modern, bahkan dengan modernnya dunia ini persaingan semakin ketat dan ini menjadikan agen/aktor mencari jalan untuk mengatasinya. Salah satunya adalah berdoa dirumah atau berdoa sekaligus mengunjungi makam (ziarah makam) yang dianggap dapat membantu mempermudah jalannya doa permohonan kepada Allah SWT. Ziarah makam yang dimaksud adalah ziarah ke makam orang suci atau yang dianggap Wali/Sultan yang diyakini dapat menjadi mediator doa ke Allah SWT agar doanya cepat terkabul, karena makam orang suci dipercaya dapat di jadikan wasilah atau jembatan oleh agen atau aktor.

Tradisi berziarah ke makam di zaman modern ini, mungkin sudah mengurangi nilai spiritualnya, hal ini dikarenakan pola pikir manusia modern berdasarkan nalar dan logika keilmuan yang dimilikinya. wajar karena berziarah adalah bentuk komunikasi spritual atau interaksi sosial yang tidak mungkin dapat dicerna oleh akal pikiran, hanya orangorang tertentu saja yang masih banyak meyakini bahwa dengan berziarah dapat meningkatkan keimanan dan melapangkan segala persoalan dalam kehidupan ini. Ziarah Makam sudah menjadi suatu tradisi, kebiasaan (habitus) atau kegiatan yang rutin dilakukan oleh sebagian besar masyarakat Indonesia karena bangsa Indonesia masih sangat kental akan budaya dan religius keagamaannya. Budaya Indonesia sangat menghargai budaya nenek moyang yang selalu dilestarikan oleh generasi selanjutnya untuk tetap dipelihara bentuk-bentuk ritualnya agar tidak tergerus oleh keadaan zaman yang serba instan dan kurang peduli lagi akan ritual keagamaan.

Berbicara mengenai ziarah makam adalah suatu tradisi yang diwariskan secara turun-temurun dan tidak akan lekang dimakan zaman, karena ziarah makam adalah bentuk penghayatan yang sudah ter internalisasi kedalam individu atau agen/aktor atau yang disebut habitus yang sudah mendarah daging pada setiap individu yang meyakininya. Habitus yang terbentuk pada diri agen atau aktor dikarenakan oleh interaksi sosial yang 
terjalin secara intensif baik agen dengan agen, agen dengan aktor maupun aktor dengan aktor. Relasi struktur dan agen/aktor ikut bermain dalam hal ini.

\section{Arena Kekuasaan Simbolik}

Suatu kekuasaan simbolik dapat ditunjukkan dengan suatu penampilan yang diperankan oleh individu ataupun kelompok. Sikap atau perilaku pulalah yang menyebabkan Kekuasaan simbolik menjadi jelas menilai seseorang atau kelompok untuk menunjukkan jati dirinya. Kekuasaan simbolik di definisikan untuk mengiring pengakuan serta Pandangan. Ini sudah terbukti dengan jelas dimulai zamannya orde lama, orde baru, sampai orde reformasi tahun 2014, perlu sangat hati-hati.

Korelasi kekuasaan simbolik dengan ziarah makam merupakan hubungan sosial bagi individu maupun masyarakat dalam melakukan aktifitas ziarah makam, kekuasaan simbolik sebagai sesuatu yang wajar karena dalam diri individu telah tertanam suatu bentuk kekuasaan yang tanpa disadari oleh individu tersebut. Kekuasaan simbolik dapat ditunjukkan oleh kelompok Islam terbesar di Indonesia yaitu Nahdhatul Ulama yang mengharuskan melakukan ziarah makam. Bagi warga NU, ziarah makam memang menjadi tradisi dari generasi ke genarasi. Warga NU tidak hanya melakukan ziarah makam ke nenek moyangnya yang telah mendahuluinya, tapi juga ke makam para Kyai, Ulama dan Waliyullah. Yang menarik, kini ziarah makam tidak hanya dilakukan oleh warga NU, tapi juga menjadi tradisi bangsa Indonesia secara umum. Bahkan organisasi keagamaan Islam tertua Muhammadiyah yang semula melarang warga muhammadiyah melakukan ziarah makam, kini malah menganjurkan dan menghukumi sunnah. Sikap berbalik 180 derajat Muhammadiyah itu terjadi setelah makam tokoh Muhammadiyah Ki Bagus Hadikusumo hilang. Ki Bagus Hadikusumo adalah ketua umum Pengurus Pusat (PP) Muhammadiyah periode 1944 hingga 1953.

Oleh karena itu, Ketua umum PP Muhammadiyah Prof. Dr Haedar Nashir menekankan pentingnya ziarah makam. seperti dikutip Tempo.co. Ia mengungkapkan bahwa Nabi Muhammad SAW mengajarkan, jika berziarah makam maka ingatlah kematian. Menurut Haedar, ziarah dapat digunakan mengenang teladan orang dan mengikuti amalnya. Contoh : Seorang Kyai atau pimpinan pondok pesantren selalu melakukan ziarah makam, hal ini selalu dilakukan secara rutin. Rutinitas Kyai tersebut tanpa banyak bicara akan diikuti oleh santri atau masyarakat yang memperhatikannya. Kyai tersebut mempunyai berbagai modal yang tentunya individu berharap suatu saat akan seperti kyai tersebut. Yang perlu diwaspadai adalah kita harus selalu mencurigai bahasa yang dipakai, wacana dan tanda dengan ataupun simbol yang digunakan sebagai ciri kekuasaan simbolik.

\section{Kesimpulan}

Kesimpulan ini, penulis uraikan berdasarkan hasil wawancara dengan berbagai pihak. Penelitian ini dilakukan tepatnya di kompleks pemakaman keluarga Sultan 
Maulana Hasanudin desa Banten Kecamatan Kasemen, Kota Serang- Banten. Hasil dari wawancara dengan berbagai pihak diantaranya : Peziarah, Pihak Kenadziran, Petugas Parkir, Petugas Kebersihan, Pedagang, Camat Kasemen dan lain-lain. Penulis dapat menyimpulkan berbagai hal. Mengenai tradisi ziarah makam jelas dilakukan oleh kaum nahdiyin, hal ini menurut keterangan dari pihak kenadziran makam yang di cross check dengan hasil wawancara dengan para peziarah. Kaum Nahdiyin masih melestarikan dan memegang teguh ajaran nenek moyangnya, kegiatan keagamaan berupa ziarah makam walaupun hal itu adalah bentuk suatu tradisionalisme, tetapi menjadi warisan sebuah budaya Islam dan hal itu juga suatu sunah dari Nabi Muhammad SAW, terlepas dari niat aktor/agen dalam memaknainya ziarah tersebut, ziarah makam tersebut tetap saja selalu ramai di datangi oleh para pemburu berkah. Apalagi saat ini ziarah makam bagaikan sebuah pasar rohani yang banyak di datangi masyarakat dari berbagai kalangan. Makam sebagai penyedia berkah dan sebagai wasilah (jembatan), sementara peziarah sebagai konsumen berkah dan mengharapkan jembatan sebagai perantara doa dan niat yang di inginkan segera cepat terkabul. Menurut penafsiran, ziarah makam bukanlah suatu bentuk perintah, tapi merupakan suatu pembolehan yang dicontohkan oleh Nabi Muhammad SAW. Karena sebelumnya ziarah makam adalah dilarang, kemudian ziarah makam ini diperbolehkan untuk dilakukan dengan berbagai syarat keutamaannya, seperti larangan "jangan berkata-kata yang keji", termasuk yang berkata keji adalah berkata dalam hati, berkeyakinan dalam hati bahwa penghuni makam dapat menolong manusia yang masih hidup. Jadi kesimpulan ziarah makam tidak diperintahkan, melainkan adabadab ketika berziarah makam yang diatur, agar jangan sampai menabrak laranganlarangan yang lain. Ziarah makam bukanlah ibadah yang diperintahkan. Melainkan hanya diperbolehkan dan diizinkan, karena penulis tidak menemukan satu dalilpun yang memerintahkan ziarah makam harus dilakukan. Ziarah makam diperbolehkan dengan syarat-syarat tertentu "Jangan berkata-kata yang keji" walaupun didalam hati. Begitu juga, ziarah makam sudah banyak dijadikan suatu arena wisata religi yang menyediakan berbagai keperluan untuk yang datang dengan berbagai macam fasilitas yang menyenangkan sehingga ziarah makam dianggap biasa-biasa saja dan menjadikan nilai spiritualnya mulai berkurang, apalagi di saat-saat ini, zaman sudah modern dan banyak orang yang mengedepankan rasionalitas dibandingkan dengan tradisionalitas. Ziarah makam mengubah perilaku seseorang untuk menjadi lebih baik lagi dan ziarah makam juga dapat mengubah citra yang selama ini seram dan keramat menjadi suatu arena yang menentramkan jiwa dan tempat untuk berbagai kegiatan baik spiritual maupun keduniawian karena arena makam dapat dijadikan berbagai aktifitas untuk berbagai kegiatan yang positif.

\section{Daftar Pustaka}

Abdullah, Irwan. (2006). Konstruksi dan Reproduksi Kebudayaan. Yogyakarta: Pustaka Pelajar 
Agustian, Ary Ginanjar. (2001). Rahasia Sukses Membangun Kecerdasan Emosi dan Spiritual ESQ. Jakarta: Arga

Ahmad, ER.Taufik Iksan, Denyut Budaya Banten, Penerbit : Leppenas STIE . Banten.

Amedeo, Giorgi. (2009). The Desrciptive Phenomenological Method in Psychology: a Modified Husserlian Approach. Duquesne University Press.

Amin, Syaifullah. Islam Nusantara-Makam Aulia Raja Ilato Ramai Dikunjungi Peziarah. http://www.nu.or.id Diakses, 18 maret 2018.

Anshari, Hafi. (1993). Pamahaman dan Pengalaman Dakwah (Pedoman untuk Mujahid Dakwah), Surabaya: Al-Ikhlas

Anthony Gidden dkk. (2004).Sosiologi sejarah dan Berbagai Pemikirannya, Yogyakarta Kreasi Kencana

Arifin, Bey. (2004). Hidup Sesudah Mati. Jakarta: Kinta Cet. Ke XIV.

Arifin, Imron. (1993). Debus, Ilmu Kekebalan dan kesaktian Dalam Tarekat Rifa'iyah.

Arikunto, Suharsimi. (2006), Penelitian Tindakan Kelas, Jakarta: Bumi Aksara.

Asnawi, Sibtu. (1996). Adab Tata Cara Ziarah Kubur. Kudus: Menara.

Bachtiar, Edi. (2014). Sholat Sebagai Media Komunikasi Vertikal Transendental, Jurnal Bimbingan Konseling Islam, Vol 5 (2)

Bakri, Syamsul. (2009). The Power Of Tasawuf Reiki : Sehat jasmani Rohani Dengan Psikoterapi Islami. Yogyakarta : Penerbit Pustaka Marwa,

Batanji, Ibnul. (2013). Bila Kuburan Di Dewakan, Al-Marfu’i (Ed). Solo: Pustaka Arafah.

Bourdieu, P. (1986). Handbook of Theory and Research For The Sociology Of Education. (J.Richardson Terj.) Westport, CT : Greenwood.

Bourdieu, P. (1991). Languange and Simbolic Power. Cambridge: Polity Press.

C. Young, C.K. (2007). Spiritual, Kesehatan, dan Penyembuhan. Medan: Bina media Perintis

Christina, Luzar laura. (2015). Teori konstruksi Realitas Sosial, Jakarta: BINUS UNIVERSITY School of Design

Chambert-Loit, Henri \& Claude Guillot. (2007). Ziarah dan Wali di Dunia Islam, Serambi Ilmu Pengetahuan.

Cameron, J. Pierce, W.D. (1994). "Reinforcement, Reward, and Intrinsic Motivation" : A Meta-Analysis. Review of Educational Reseacrh

Clive, Erricker. (2009). "Pendekatan Fenomenologis" Dalam Peter Connolly (Ed), Aneka Pendekatan Studi Agama terj.Imam Khoiri, Yogyakarta : LkiS.

C.Ekeke, Rev. Emeka dan Chike Ekeopara. (2010). "Penomenological Approach To The 


\section{At-Taqaddum}

Vol. 12 No. 2 (2020) 135-154

Study Of Religion a Historical Perspective" European Journal Of Scientific Research, Vol 44, No 2.

Dadang, Kahmad. (2000). Sosiologi Agama. Bandung: Rosda Karya.

Dadang, Suparlan. (2007). Pengantar Ilmu Sosial Sebuah kajian Pendekatan Srtuktural, Jakarta: Bumi Aksara

Daniel. L.Pals. (2001). Dekonstruksi Kebenaran Kritik Tujuh Teori Agama, Yogyakarta: IRCiSoD

Dewan Redaksi Ensiklopedi Islam. (1994). Ensiklopedi Islam. Jakarta: PT. Ichtiar Baru Van Hoeve.

Elly, M. Setiadi dan Usman Kolip. (2011). Pengantar Sosiologi Pemahaman Fakta dan Gejala Permasalahan Sosial: Teori, Aplikasi dan Pemecahannya. Jakarta: Kencana

Fajri, Fauzi. (2007). Penyingkapan Kuasa Simbol (apropriasi reflektif pemikiran pierre bourdieu). Yogyakarta: Juxtapose.

Falah, Achmad. (2012). Spiritualitas Muria: Akomodasi Tradisi dan Wisata. Journal Walisongo. Vol 20. No. 2.

Garna, Yudistira K. (2008). Budaya Sunda: Melintasi Waktu Menantang Masa Depan. Bandung: Lemlit Unpad

Gellner, Ernerst. (1992). Post Modernism, Reason and Religion London: Routledeg

Geertz, Clifford. (1983). Abangan, Santri dan Priyayi dalam masyarakat Jawa. terj Aswad Mahasin. Jakarta: Pustaka Jaya.

Giddens, Anthony. (2010). Metode Sosiologi Kaedah-kaedah baru. Yogyakarta: Pustaka Pelajar

Gus Nuril Soko Tunggal dan Khoirul Risyadi. (2010). Ritual Gusdur dan Rahasia Kewaliannya. Yogyakarta: Galang Press.

Hadi, Sumandiyo. (2006). Seni Dalam Ritual Agama, Yogyakarta : Buku Pustaka.

Hartini, G. Kartasapoetra. (1992). Kamus Sosiologi dan Kependudukan, Jakarta: Bumi Aksara

Harker, R.dkk. (2009). (habitus x Modal) + Ranah = Praktik "Pengantar paling Konprehensif Kepada Pemikiran Pierre Bourdieu.” Yogyakarta: Jalasutra

Hasbiansyah. O. (2008). Pendekatan Fenomenologi : pengantar praktik Penelitian dalam Ilmu sosial dan komunikasi. Media Tor. 9. (1)

Hendro, Puspito O.C. (1983). Sosiologi Agama, Yogyakarta: Kanisius

Hendri, Chambert-Lorir dan Guillot, Claude. (2010). Ziarah dan Wali di Dunia Islam. Depok : Komunitas Bambu 
Herdiyansyah, Haris. (2011). Metodologi Penelitian Kualitatif : Untuk Ilmu-ilmu Sosial, Jakarta: Salemba Humanika

Ismail, Ilyas. (2013). True Islam : Moral, Intelektual , Spiritual. Jakarta: Mitra Wacana Jamhari. (2000). In The Center Of Meaning : Ziarah Tradition In Java, Jakarta: Studia Islamika

Jenkin, Richard. (2016). Membaca Pikiran Pierre Bourdieu, Kreasi Wacana Yogyakarta Kaelan, (2010). Metode Penelitian Agama Kualitatif Interdisipliner. Yogyakarta: Paradigma , Hlm. 74.

Koentjaraningrat. (1992). Kebudayaan, Mentalitas dan Pembangunan. Jakarta : Gramedia Pustaka Utama.

Kuswarno, Engkus. (2009). Metodologi penelitian Komunikasi Fenomenologi. Konsepsi, Pedoman, dan Contoh Penelitiannya, Bandung: Widya Pajajaran.

M. Harjana, Agus. 2009. Religiositas, agama dan Spiritualitas. Yogyakarta: Kanisius

Maksum, Ali. 2003. Tasawuf Sebagai Pembebasan Manusia Modern. Telaah Signifikasi Konsep Tradisionalisme Islam. Surabaya: PS4M.

Maslow. (Inggris) A. (1961) "Motivation and Personality" New York: Van Nostrand Reinhold

Moleong, L.J (2014). Metodologi Penelitian Kualitatif. Bandung : Remaja Rosdakarya.

Muhammad, Yamin. (2002). Sosiologi Agama, Yogyakarta : IRCiSoD

Mujib, M. Misbahul. (2016). "Tradisi Ziarah Dalam Masyarakat Jawa" : Kontestasi Kesalehan, Identitas keagamaan dan komersial. Journal Kebudayaan Islam . Vol. 14, No 1.

Mustaghfiroh, Hikmatul dan Muhammad Mutakim. (2014). Analisis Spiritualitas para Pencari Berkah Studi atas Motivasi Ziarah di makam Sunan kalijaga kadilangu Demak. Journal Penelitian. Vol 8. (1).

Mz, Labib. (2003). Hidup Pasti Berakhir. Surabaya : Bandung Usaha Jaya.

Narwoko, Dwi J. (2006). Sosiologi Teks Pengantar dan Terapan. Jakarta : Kencana Prenada Media Group.

Narbuko, Cholid dan Ahmadi, Abu. (1999). Metodologi Penelitian. Jakarta: Bumi Aksara Nawawi, Hadari. (1995). Metodologi Penelitian Bidang Sosial. Yogyakarta : Gajah Mada University Press.

Nur Sahid. Muhammad. (2015). Yaasiin Tahlil dan Istighatsah. Semarang: Widya karya

Piedmont, R.L. (2001). Spritual Transendence and The Scientific Study Of Sprituality. Journal of Rebabilitation. Vol 67. No 1. 
Prastowo, Andi. (2011). Metode Penelitian Kualitatif dalam Perspektif Rancangan Penelitian. Yogyakarta: Ar-Ruzz Media.

Purwadi. (2006). Jejak Para Wali dan Ziarah Spiritual. Jakarta: Kompas.

Ruslan dan Nugroho, Arifin Suryo. (2007). Ziarah wali, Wisata Spiritual Sepanjang Masa. Yogyakarta: Pustaka Timur.

Simuh. (2003). Islam dan Pergumulan Budaya Jawa. Yogyakarta: Teraju

Shubhani, Syaikh Ja'far. (2010). Tawassul, Tabarruk, Ziarah Kubur, Karamah Wali termasuk Ajaran Islam. Jakarta: Pustaka Hidayah

Suwardi Endraswara. (2006). Mistis Kejawen : Sinkretik, Simbolisme dan Sifisme Dalam Budaya Spiritual jawa. Yogyakarta : Narasi

Thomas F, O’Dea. (1996). Sosiologi Agama Suatu Pengenalan Awal, Jakarta : PT Raja Grafindo Persada

Winarno, Budi. (2005). Globalisasi Wujud Imperialisme Baru. Tajidu Press: Yogyakarta 